\title{
Embedding Higher-Order Thinking Skills in the English Classroom to Address to Industrial Revolution 4.0
}

\author{
Anis Ichwati Nur Rohmah* \\ Graduate School \\ Universitas Negeri Yogyakarta \\ Yogyakarta, Indonesia \\ anisichwati.2019@student.uny.ac.id
}

\author{
Erna Andriyanti \\ Graduate School \\ Universitas Negeri Yogyakarta \\ Yogyakarta, Indonesia \\ erna.andriyanti@uny.ac.id
}

\begin{abstract}
The advancement of technology due to the Industrial Revolution 4.0 imposes students to prepare themselves with higher-order thinking skills for their professional life in the future. However, they are not familiar with learning activities involving reasonings. Therefore, teachers need to respond to the issue by embedding higherorder thinking skills in the learning activities using a deep questioning strategy. Deep questions enable students to consider a different perspective, evaluating evidence, and solving non-routine problems. This paper highlights how higher-order thinking skills learning is implemented in the English classroom using deep questions strategy to respond to the Industrial Revolution 4.0. This classroom action research reports on a teacher's experience in planning, implementing, observing and reflecting on the use of deep questioning as one of the ways to embed Higher-Order Thinking Skills in English learning activities. The results show that the deep questioning strategy combined with material selection, think-pair-share, and questions rephrasing strategies enables more students to actively participated in the class.
\end{abstract}

\section{Keywords-critical thinking, questioning, ELT}

\section{INTRODUCTION}

The industrial revolution 4.0 signified by the emerging of new technology that not only transforms the job market in the future but also revolutionizes the way we see the future. One of the characteristics of the disruptive era of the industrial revolution 4.0 is the shift of jobs available in the 21 st Century. The jobs relying on the possession of knowledge of a particular field will get automated due to the emergence of technology in the field, among others, machine learning, big data, and the Internet of Things (Schwab, 2016; Levy \& Murnane, 2004; Xu, David, \& Kim, 2018)

In terms of professional life, teachers must also prepare students for jobs that have not yet existed or the ones that would not be automated. The exponential speed of technology enables students to access knowledge in a matter of seconds from the internet. Consequently, the issue is not about 'what you know,' but more importantly, on 'how you use what you know.' Thus, students need to go beyond the mastery of core content in each subject to the mastery of skills dealing with uncertainty and unfamiliarity. To address the issue, preliminary studies involving business communities, education leaders, and policymakers outlined the 21 st Century skills required for the competencies required for future job markets. (Partnership for 21st Century Learning, 2015, 2019; Trilling \& Fadel, 2009)

In the Indonesia context, the new curriculum (Kurikulum 2013) adopt the 21 st Century skills into the classrooms. The 2018 Regulation of the Education and Culture Ministry Number 34 about the Content Standard of the Vocational School Curriculum has mentioned critical thinking (HigherOrder Thinking Skills) as one of the indicators in the scope of materials integrated into the classroom practices. However, the percentages of students answered correctly in the 2019 vocational high school English national examination for social function, text structure, language features were below 50\% (consecutively $47.36 \%, 35.79 \%$, and $38.42 \%$ ). Meanwhile, the average English score for vocational high schools is 41.78 (the National Center for Educational Evaluation or Pusat Penilaian Pendidikan/Puspendik, 2019). The average is lower from the ones of high schools majoring in the language (49.13), natural science (53.58), and social science (44.78). The data implied that the learning process needs to be improved by embedding Higher-Order Thinking Skills (HOTS)

HOTS learning means providing them with meaningful and contextual topics that are relevant to the real world. The learning activities involve analysis, evaluation, and creation. It includes the ability to be logical, creative, and reflective that will emerge when one encounters unfamiliar problems, uncertainties, questions, or dilemmas. Deep questioning is one of the strategies to enable students to think beyond the surface structure of the text, relate it to other subjects, the local and global context, as well as their own experience and learning. (Fullan \& Langworthy, 2013; Hamiloglu \& Temiz, 2012; King, Goodson, \& Faranak, 2004)

To facilitate students learning higher-order thinking skills in English class, teachers need to provide necessary scaffolding to construct the knowledge as well as solve the problem themselves. It is necessary to ensure that challenging tasks along with necessary assistance. In terms of deep questioning, a teacher may give scaffolding in the form of asking surface questions in the early stages and go deeper as the students develop their thinking skills (Lai, 2011; King et al., 2004; Celce-Murcia, 2001; Aziz, Ahmad, Ismail, Ibrahim, \& Samat, 2017)

Several studies related to the implementation of HOTS learning in the ESL/EFL classroom showed that teaching 
HOTS contributes to students' learning. A study conducted for Iranian students indicated that the use of higher-order thinking strategies showed positive effects on learners reading skills (Nourdad, Masoudi, \& Rahimali, 2018). According to the results, the instruction of higher-order thinking skills helped EFL learners improve their reading comprehension ability (Nourdad et al., 2018). This paper highlights how higher-order thinking skills learning is implemented in the English classroom using deep questions strategy. The researcher implemented a deep questioning strategy described in this paper in a vocational high school.

\section{A. Industrial Revolution 4.0}

As a law of nature, dynamic changes to human life always occur from time to time, along with the development of science and technology at an exponential rate. Thus, we are now facing the beginning of the Industrial Revolution 4.0. There will be much more ubiquitous and mobile internet, by smaller and more powerful sensors that have become cheaper, and by artificial intelligence and machine learning. (Schwab, 2016)

Meanwhile, labor markets will be disrupted by the advancement of technology at such an exponential rate in such a way that automation may displace workers by machines. Although it is also possible that the displacement of workers by technology will increase in safety and rewards in professional life (Schwab: 2016). Nonetheless, the changing in the map of skills needed in the workplace is unavoidable. The following figure shows jobs requiring routine and manual skills and those with high demands for complex communicating and thinking skills.

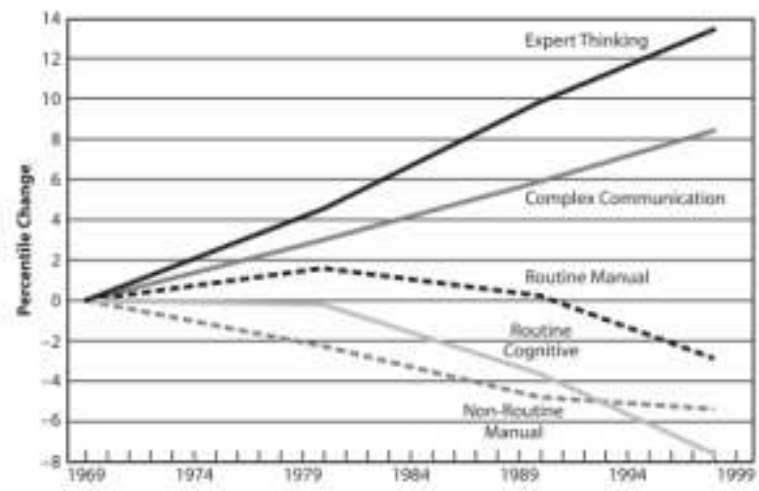

Fig. 1. Economy-Wide Measures of Routine and Non-Routine Task (Levy \& Murnane, 2004)

Thus, education plays a role in preparing students to contribute to work and society, fulfill personal talent, fulfill civics responsibilities, carrying forward, as well as tradition and values ((Trilling \& Fadel, 2009).

\section{B. $\quad$ The 21st Century Learning}

Fullan \& Langworthy (2013) suggested the need to renew the goals for education and learning. It is necessary to include skills that prepare all learners to contribute to the common good in today's globally interdependent world through a set of skills. Such a skill named Deep Learning comprises character education, citizenship, communication, critical thinking and problem-solving, collaboration, as well as creativity and imagination. Further, the indicators for critical thinking and problem-solving are thinking critically to design and manage projects, solve problems, and make effective decisions using a variety of digital tools and resources.

Combining several other frameworks, a more systematic framework to the $21^{\text {st }}$ Century Skills comprising three main fields clusters Foundational Knowledge, Meta Knowledge, and Humanistic Knowledge (Kereluik, Mishra, Fahnoe, \& Terry (2013).

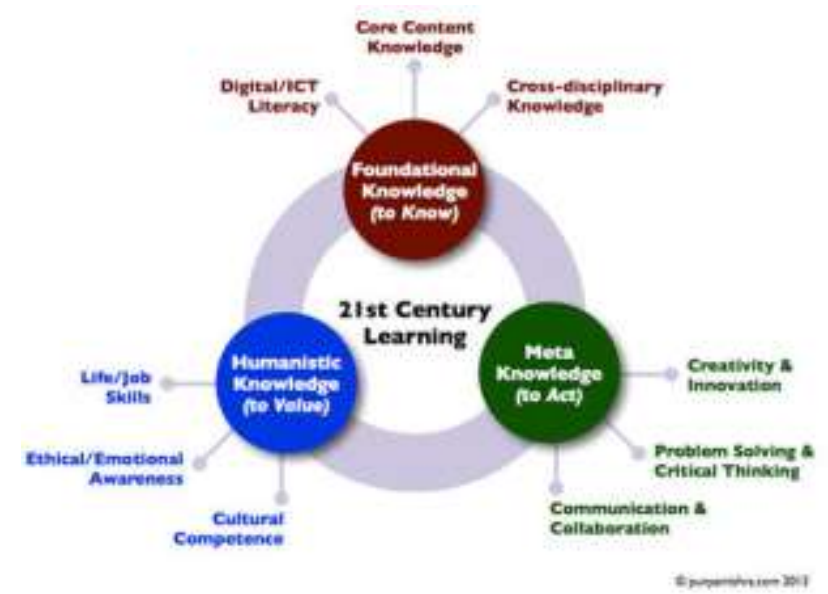

Fig. 2: The $21^{\text {st }}$ Century Learning Framework (Kereluik, Mishra, Fahnoe, \& Terry, 2013)

Based on the figure above, foundational knowledge answers the purpose of 'to know'. It consists of core content knowledge, cross-disciplinary knowledge, and digital/ICT literacy. In the English classroom, core content knowledge refers to the social function, text structures, and linguistic features of a text. Meanwhile, the cross-disciplinary knowledge integrates and synthesizes information from across fields or domains other than English subject. Meanwhile, digital/ICT literacy is defined as the ability "to effectively and thoughtfully evaluate, navigate, and construct information using a range of digital technologies and thus to function fluently in a digital world. ... includes a component of responsible use of technology and media, an important moral and ethical consideration ..."

Meanwhile, humanistic knowledge offers a vision of the learner's self and its location in a broader social and global context. In terms of meta knowledge, Mishra, Fahnoe, \& Terry (2013) adopt the learning skills framework proposed by Partnership for the 21 st Century which is also cited by Trilling and Fadel (Trilling \& Fadel, 2009), that is problem solving \& critical thinking, creativity \& innovation, and communication \& collaboration.

Further, (Griffin \& Care, 2018) proposes the interrelation of the 21st Century skills under the headings of ways of thinking, ways of working, tools for working, and living in the world. Ways of thinking also has common elements of creativity and innovation, critical thinking, decision making, and problem-solving. Meanwhile, ways of working comprises the same elements of communication and collaboration. Griffin and Care add the element of information literacy and ICT literacy in the tools for working, as well as the elements of citizenship, life and 
career, personal responsibility, and social responsibility in the aspects of living the world.

\section{Higher-Order Thinking Skills}

Higher-Order Thinking essentially means thinking that takes place in the higher levels of the hierarchy of cognitive processing. Higher-order thinking skills include critical, logical, reflective, metacognitive, and creative thinking. They are activated when individuals encounter unfamiliar problems, uncertainties, questions, or dilemmas (King, Goodson, \& Faranak, 2004).

Bloom's taxonomy revised by Anderson \& Krathwohl (2001) states six dimensions of a cognitive process. The lowest one is 'remember', involving the cognitive process of retrieving relevant knowledge from long-term memory. The next one is 'understand' of which cognitive process is constructing meaning from instructional messages, including oral, written, and graphic communication. The next level is 'applying' which means carrying out or using a procedure In a given situation. These three dimensions are usually referred to as the lower-order in the hierarchy of cognitive dimensions.

Meanwhile, 'analyze' means breaking material into its constituent parts and determine how the parts relate to one another and lo an overall structure or purpose. Then, above it is 'evaluate' that means 'making judgments based on criteria and standards'. Finally, at the top is 'create' which means putting elements together to form a coherent or functional whole; reorganizing elements into a new pattern or structure. The levels of analyze, evaluate, and create belong to higherorder thinking skills.

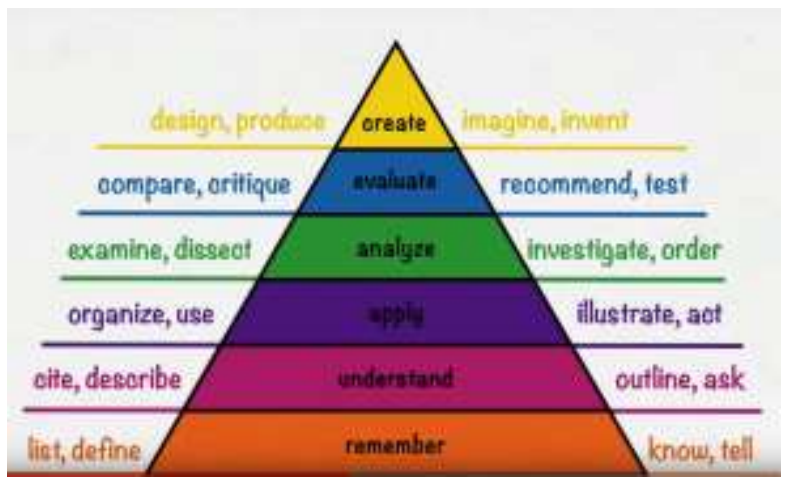

Fig. 3: Bloom's Taxonomy (revised by Anderson \& Krathwohl, 2001)

Higher-order thinking is closely related to critical thinking. Fullan \& Langworthy (2013) defines critical thinking as "think critically to design and manage projects, solve problems, make effective decisions using a variety of digital tools and resources." Similarly, Trilling \& Fadel (2009) stated that critical thinking is the ability to analyze, interpret, evaluate, summarize, and synthesize all this information. Further, Partnership for 21st Century learning (2015) outlined the following indicators for critical thinking and problem-solving.

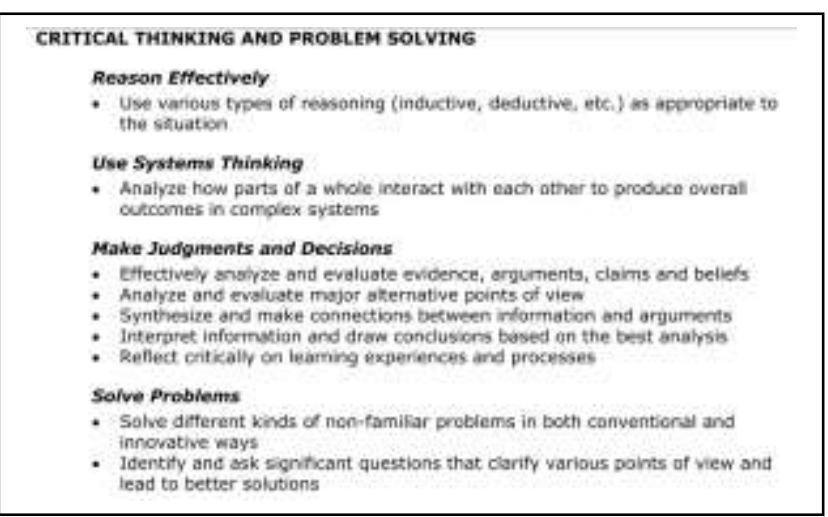

Fig. 4: Indicators for Critical Thinking and Problem Solving

However, in teaching Higher-Order Thinking Skills, students must get the scaffolding they need to reach highorder reasoning. Kauchak and Eggen (1998) as cited by (King et al., 2004) propose that in providing structured representations and discussions of thinking tasks, teachers can visually represent and organize problems in drawings, graphs, hierarchies, or tables. They can also discuss examples of problems and solutions, explaining the nature of problems in detail and relating the worked-out solutions to the problems. This practice reduces the student's need for additional teacher assistance.

Before using deep questions, teachers use scaffolding to create opportunities for practice in solving problems by providing teacher-directed practice before independent practice, spot-checking progress on practice, and providing short responses of less than 30 seconds to any single request for assistance. Besides that, teachers can assign frequent, short homework assignments that are logical extensions of classroom work (not more than 20 minutes for elementary students). Another alternative is by linking practice in the content area to complex, real-life situations (Kauchak \& Eggen, 1998 in King et al., 2004).

\section{Deep Questions}

To embed those subskills in critical thinking teacher use many kinds of strategies. One of the strategies used is using deep questions. Questioning techniques is one of the strategies to teach critical thinking. Teachers posing better questions that evoke and facilitate critical thinking would be a good model for the students.

An empirical study about teachers' questions across 10 research reports conducted in 2013 concluded that the most effective teaching practice is when the teachers asked a variety of questions drawing on students' backgrounds. The questions ranged from closed, recall questions to higherorder, open questions with feedback embedded through elaboration, rephrasing and probing (Westbrook et al., 2013). Closed questions are factual and focus on the correct response. Meanwhile, open questions refer to questions that will have a variety of answers depending on the depth of the students' thinking. To facilitate students answering deep questions, the teachers must ensure that the students have no problem answering surface questions. Therefore, since the beginning of the school year, the subskills of reading must be taught. 
Meanwhile, a research about learning higher-order thinking skills through storytelling by Setyarini, Muslim, Rukmini, Yuliasri, \& Mujianto (2018) suggests that students' ability to come up with some possible solutions to the problems offered through these questions show their ability to transfer problem into another context and offer a solution. Another study on question-posing capabilities among students showed that the low-achieving students increased the solution orientation of their questions (Zohar \& Dori, 2003). Yet, those studies have not specifically reported the implementation of deep questioning in English language teaching in the classroom.

\section{METHOD}

This action research study reports on a teacher's experience in teaching English for second graders in one of the classes of a public vocational high school in Indonesia. The school consisted of 24 classes of three grades and four majors; thus, there were two parallel classes for each grade and each major. The majors were Electrical Installation Engineering, Computer and Network Engineering, Welding Engineer, and Audio-Video Engineering. The classroom action research was conducted in the third grade of Computer and Networking Engineering consisting of 32 students. Even though considered better than the other classes of the same grade, the students' competence was relatively low. Moreover, they had just returned from their 3-months internship program in local companies.

The study was conducted in three cycles, each cycle comprised of planning, implementation, observation, and reflection. In the planning step, the teacher prepared a lesson plan, including a set of surface and deep questions. The plan was then executed in the implementation covering 2-3 meetings. During the implementation, the students' responses were observed in terms of the changes in the students' and the teacher's behavior. The teacher was then reflected upon the results of the observation. The reflection was focused on the way the changes affected the students' learning and the teacher's teaching. The reflection was also focused on how to improve the practice and what would be the focus for the following action including the second and third cycles.

The data were collected using observation and interviews which were then analyzed qualitatively. A colleague teaching English in the same grade acted as a collaborator who observed and took notes. She was also involved in collecting data from the students and provided inputs related to the implementation. Her input was taken into consideration in the reflection process. All data collected during the cycles were triangulated in terms of the source of information and the variety of data collection techniques.

\section{FINDINGS AND DISCUSSION}

The first round focused on asking deep questions. The topic of the meeting was 'Personal Letter'. The learning objectives for the meeting are (1) after discussing the text, students are able to analyze a personal letter about future activities and (2) after practicing, students are able to write a personal letter about future activities. The deeper learning objectives are: (1) students are able to reflect on the experience of using a letter to communicate plans with others and (2) students are able to reflect on sharing plans with others. The activities in the first round are making questions based on a personal letter text, identifying the future tense, and writing a personal letter about future activity.

Students were still shy to express themselves. Some needed more time to answer deep questions. Given a personal letter, students also learned to consider the perspective of the writer. Even when they had to switch into L1, they could answer questions that involved reasoning or higher-order thinking. When the teacher asked them to ask questions about a letter, some students came up with higherorder questions referring to implied details, like the relationship of the sender and the recipient, why the sender wrote a particular expression in the sentence, or what benefit would the writer get after sending the letter. They were then assigned to write letters about future plans to their friends. The letters were delivered to the intended recipient. The students were enthusiastic because they wrote 'real' letter, communicating their 'real' plans to 'real' people.

Implementing the first round, the teacher tried to give students time to answer the questions. However, most students were still unresponsive to answer the teacher's questions. Long pauses were ended with the teacher answering her own questions. Some students stated that they did not know how to answer the questions in a long English sentence. However, they were also too shy to answer them in L1 too. After conducting the first round, the problem was not only about making the students to answer deep questions, but also to answer even surface questions given. The teacher reflected on the implementation and decided to choose the texts related to the students' major for the next round and using think-pair-share to improve students' engagement and improve their confidence.

In the second round, the focus is on asking deep questions using texts related to the students' major. The topic for the meeting was a procedure text. The learning objectives were (1) after discussing the text, students can analyze a procedure text related to their field of study; and (2) after practicing, students are able to write a procedure text related to their field of study. The deeper learning objectives were (1) students are able to relate what they learn with procedure texts related to field of study and in their jobs later; and (2) students are able to consider which steps are more efficient in a particular procedure related to their field of study. The activities in the second round were asking questions about a procedure text, identify the transition signal and the imperatives, comparing two texts to decide which one was easier to understand, and writing a modification of a procedure text on their field to make it more efficient and reader-friendly. Therefore, students also learned problemsolving given the imaginary situation that their department needs to revise the procedure text to make it easier to follow.

The students were still guided with surface questions before going deep. The teacher used the think-pair-share strategy. The students were given more time to discuss the questions with their pair. The teacher limited only three questions for every point of discussion to keep the focus. The questions developed from surface to deep questions. The students directly responded to the teacher's questions with their pair. The teacher then asked the students to answer 
loudly. The students could answer why the first texts they found were difficult to understand. They then proposed the revision of the texts to make it easier to understand.

More students responded to teachers' questions even when she asked HOTS questions. The students agreed to the notion that they felt more confident answering open-ended questions because such questions did not require single correct answers. Any answers would be fine because it would not be completely wrong. When the students could not find the word in English, they switched to L1. However, there were still many students who did not respond to the HOTS questions, even in L1. They said that they were shy.

However, the fact that more students engaged in the lesson show that the practice had improved. Using a model text as the example of text they need to find, the students could find various texts related to their field to revise. Reflecting on the implementation, the teacher felt that preparing lists of both surface and deep questions beforehand was helpful when she led students to reach higher-order thinking. She thought she would also need to rephrase and breakdown the questions to facilitate students answering higher-order questions in English. For the next round, she would assign the students to find one object in their workshop and describe it as a generic object. They were considering that working with real objects in their major would improve their confidence.

The third round focused on asking deep questions using texts related to the students' major. The topic for the meeting was report text. The learning objectives were (1) after discussing the text, students are able to analyze a procedure text related to their field of study and (2) after practicing, students are able to write a procedure text related to their field of study. The deeper learning objectives were (1) students are able to relate what they learn with procedure texts they need for their field of study and in their jobs later; and (2) students are able to evaluate evidence provided in the text. The learning activities were discussing a model text related to the social function and text structure; identifying passive sentences, its pattern, then apply the grammatical rule by writing sentences for describing an object in general; and writing a description of an object from their workshop as a generic object.

The teacher still used the think-pair-share strategy. When learning the grammar, the students were asked to comment on their friends' sentences. When they were unsure whether a sentence was correct or not, they were encouraged to confirm it by searching the internet. Thus, they had to be able to provide evidence to support their judgment. The teacher also breakdown the HOTS questions, using simple sentences, to help students answered the HOTS questions in English. Although the material of the report text was considered rather complicated, the students seemed enthusiastic about doing the activities. They commented that they were tired because they had to think hard, but they enjoyed the opportunity to walk to the workshop and browse the internet. However, due to the complexity of the material, some students still unable to explain the description of the objects in English, especially when it required long sentences.

Evaluating from the result of the implementation, the teacher learned that preparing deep questions embedded in activities provided variation in the classroom. The teacher provided sufficient assistance that the students could do complicated tasks requiring critical thinking enthusiastically as well as answered HOTS questions with simple English. The students submitted the correct text structure of the report text, providing the picture of the object. Compared to the first and second cycles with easier materials, the increase of grammatical errors in students writing was unavoidable. To the teacher, it was quite understandable since students always struggled with grammar in any complicated functional text. The results of the actions are described in the following table.

TABLE 1: THE RESULTS OF THE ACTION FROM TIME TO TIME

\begin{tabular}{|c|c|c|c|}
\hline & CYCLE 1 & CYCLE 2 & CYCLE 3 \\
\hline $\begin{array}{l}\text { Students's } \\
\text { Participation }\end{array}$ & $\begin{array}{l}\text { Not much participation } \\
\text { in responding to HOST } \\
\text { questions. Only when } \\
\text { the questions was in } \\
\text { L1, more students } \\
\text { responded (in L1). }\end{array}$ & $\begin{array}{l}\text { Using think-pair-share, students could } \\
\text { answer HOTS questions sharing it } \\
\text { with their partners. In class } \\
\text { discussion, more participation in } \\
\text { responding to HOTS questions; most } \\
\text { students still switched to L1. }\end{array}$ & $\begin{array}{l}\text { More participation in } \\
\text { answering HOTS questions } \\
\text { relating supporting judgement } \\
\text { with evidence (about } \\
\text { grammar) using simple L2 } \\
\text { during class discussion. }\end{array}$ \\
\hline \multicolumn{4}{|l|}{ Students's Achievement } \\
\hline $\begin{array}{l}\text { Average score for } \\
\text { reading test }\end{array}$ & 71 & 73 & 71 \\
\hline $\begin{array}{l}\text { Average score for } \\
\text { Writing assignment }\end{array}$ & 87 & 88 & 83 \\
\hline
\end{tabular}

The implementation of the first cycle revealed the lack of confidence among the students to voice their opinions. It was even after the teacher broke down the questions to several simpler questions and gave more time to answer the questions. The result was quite unexpected because a case study in London introducing the pose, pause, pounce, bounce questioning technique (PPPB) worked well. The strategy involves posing a question, pausing to give pupils time to think, pouncing on one individual for an answer, and then bouncing that answer on to another pupil. Teachers said that it improved the children's listening skills and that it encourages children to consider alternative thinking and to build on that thinking (British Council, 2017) 
However, it is quite understandable that higher-order thinking occurs when a person takes new information. The information is stored in memory and interrelates and/or rearranges and extends this information to achieve a purpose or find possible answers in perplexing situations (Lewis \& Smith, 1993; Anderson \& Krathwohl, 2001). To do so, students do need a lot of practice.

Meanwhile, the use of the think-pair-share strategy in cycle two gave a contribution to the engagement of the students during the lesson as the strategy made them feel more confident. It confirms a study to the tenth-grade English learners in Taiwan. The study indicated that thinkpair-share in reading strategy instruction is more effective in increasing motivation compared to the traditional one (Shih \& Reynolds, 2015). Learning activities and assessment tasks that call for critical thinking may spark student motivation because they are more challenging, novel, or interesting (Lai, 2011).

The teacher's preparation in making a list of surface to deeper questions helped ensure the flow of interaction to provide assistance for students to answer the intended questions (Fullan \& Langworthy, 2013). It confirms Kauchak and Eggen (1998) statement in King, Goodson, \& Faranak (2004) that teachers can use scaffolding with a variety of examples to describe the thinking processes involved. Teachers can also use scaffolding only when needed, by first checking for understanding and, if necessary, providing additional examples and explanations. Teachers are also possible to use scaffolding to build on student strengths and accommodate weaknesses.

In the third cycle, the students were asked to provide evidence when commenting on their friends' work. It is in line with Willingham's statement (2007) that critical thinking is effective when it follows several conditions. It should consider different perspectives, evaluates new evidence that disconfirms ideas, reasons using logical, not merely passion, and supports the statement with evidence (Fullan \& Langworthy, 2013). Critical thinking contains novelty. In other words, students do not use a solution that is similar enough to guide them; instead, they must use a new approach to the situation. Critical thinking is self-directed that students do not require too much assistance.

In this cycle, the students also enjoyed describing an object in the workshop in a generic way. The activity is related to their field of study, and thus it would relate to their future job. Mishra \& Mehta (2017) argue that the learning of critical thinking, creativity, communication, and collaboration is not content-neutral. The acquisition of the learning skills requires the mastery of disciplinary (core content) or interdisciplinary knowledge. Thinking that disciplinary and interdisciplinary knowledge is less important would be inaccurate. Teaching critical thinking means that teachers must facilitate students to have a sound understanding of both pieces of knowledge that serves as the content for the learning (Trilling \& Fadel, 2009). The results were also consistent with a study by Hamiloglu \& Temiz (2012) about teachers questioning, “... divergent questions are more challenging ones including open-ended, referential, and non-retrieval/imaginative questions. To provide a free production and active use of the target language, thus divergent questions are important and necessary means of classroom questioning".

\section{CONCLUSION}

The research focus was on asking deep questions in teaching English in vocational high schools. The first cycle material was not specified in the students' field of study. However, the second and third rounds used materials related to the students' field of study. In the first round, not many students responded to the teacher's questions. However, after the teacher implemented a think-pair-share strategy starting from the second round, more students participated in responding to the teacher's questions. In the beginning, answering HOTS questions was too difficult for the students. Most of them answered the questions in L1 that in the third round the teacher decided to rephrase of break down the questions into simple sentences to help students answered the questions. Using the combination of text choice, think-pairshare, and questions rephrasing, more students were engaged in the lesson.

In terms of deep learning, the students had learned different perspectives, problem-solving, and assessing the evidence. Answering HOTS questions related to their field of study provided them chances to give answers to 'an expert.' They enjoyed the materials related to their field of study in which some terms were already familiar. They believed that what they learned in English class would be useful in their vocational subjects and their future job. On the teacher's side, she worked harder to select text materials and preparing a list of questions.

Although the implementation received positive responses from the students, one of the limitations of this study is the insufficient time for each basic competence that some students complained about the fast-pacing instruction. For further studies, it is necessary to explore the contribution of deep questions to students' performance.

However, this study has shown that it is possible to integrate Higher-Order Thinking Skills into English learning activities. The combination with several other teaching strategies and the implementation of sufficient scaffolding enable the students to learn higher-order thinking skills while improving their English competency.

\section{ACKNOWLEDGMENT}

The researcher would like to thank the Indonesian Endowment Fund for Education (Lembaga Pengelola Dana Pendidikan / LPDP) for the support of the study.

\section{REFERENCES}

Anderson, L. W., \& Krathwohl, D. R. (2001). A taxonomy for learning teaching and assessing: a revision of Bloom's taxonomy of educational objetives. New York: Longman.

Aziz, A., Ahmad, A., Ismail, F., Ibrahim, N. M., \& Samat, N. A. (2017). Investigating the Implementation of Higher Order Thinking Skills in Malaysian Classrooms: Insights from L2 Teaching Practices. Sains Humanika, 9(4-2), 65-73. https://doi.org/10.11113/sh.v9n42.1361

British Council. (2017). Unlocking a world of potential. London: Author

Celce-Murcia, M. (2001). Teaching English as a Second or Foreign Language (3rd ed.). New York: Heinle \& Heinle.

Fullan, M., \& Langworthy, M. (2013). Towards a New End: New Pedagogies for Deep Learning. Retrieved from 
www.newpedagogies.org

Griffin, P., \& Care, E. (2018). Educational Assessment in an Information Age Assessment and Teaching of 21 st Century Skills: Research and Applications [1 ed.]. https://doi.org/10.1007/978-3-319-65368-6

Hamiloglu, K., \& Temiz, G. (2012). The Impact of Teacher Questions on Student Learning in Efl. International Conference on New Trends in Education and Their Implications - ICONTE, 2(2), 1-8. Antalya: Journal of Educational and Instructional Studies.

Kereluik, K., Mishra, P., Fahnoe, C., \& Terry, L. (2013). What Knowledge Is of Most Worth: Teacher Knowledge for 21 st Century Learning. Journal of Digital Learning in Teacher Education, 29(4), 127-140. https://doi.org/10.1080/21532974.2013.10784716

King, F. J., Goodson, L., \& Faranak, R. (2004). Higher order thinking skills: Definition, teaching strategies and assessment. Florida.

Lai, E. R. (2011). Critical Thinking: A literature review. In Pearson. Retrieved from http://www.pearsonassessments.com/research.

Levy, F., \& Murnane, R. J. (2004). The New Division of Labor: How Computers are Creating the Next Job Market. Princetion: Princeton University Press.

Lewis, A., \& Smith, D. (1993). Defining Higher Order Thinking. Theory Into Practice, 32(3), 131-137. https://doi.org/10.1080/00405849309543588

Mishra, P., \& Mehta, R. (2017). What We Educators Get Wrong About 21st-Century Learning: Results of a Survey. Journal of Digital Learning in Teacher Education, 33(1), 6-19. https://doi.org/10.1080/21532974.2016.1242392

Partnership for 21st Century learning. (2015). P21 Framework Definition. Retrieved from http://www.p21.org/our-work/p21-framework

Partnership for 21st Century Learning. (2015). Framework for 21 st century learning definitions. In Partnership for 21st Century Learning. Retrieved from

http://www.battelleforkids.org/networks/p21/frameworks-resources
Partnership for 21st Century Learning. (2019). Framework for 21st Century Learning. In Partnership fo 21 st century learning. Retrieved from http://www.battelleforkids.org/networks/p21/frameworks-resources

Schwab, K. (2016). The Fourth Industrial Revolution. Geneva: World Economic Forum.

Setyarini, S., Muslim, A. B., Rukmini, D., Yuliasri, I., \& Mujianto, Y. (2018). Thinking critically while storytelling: Improving children's HOTS and English oral competence. Indonesian Journal of Applied Linguistics, 8(1), 189-197. https://doi.org/10.17509/ijal.v8i1.11480

Shih, Y. C., \& Reynolds, B. L. (2015). Teaching Adolescents EFL by Integrating Think-Pair-Share and Reading Strategy Instruction: A Quasi-Experimental Study. RELC Journal, 46(3), 221-235. https://doi.org/10.1177/0033688215589886

Trilling, B., \& Fadel, C. (2009). 21st Century Skills: Learning for Life in Our Times (1st ed.). San Fransisco: Jossey-Bass.

Westbrook, J., Durrani, N., Brown, R., Orr, D., Pryor, J., Boddy, J., \& Salvi, F. (2013). Pedagogy, Curriculum, Teaching Practices and Teacher Education in Developing Countries: Final Report. In Education Rigorous Literature Review. Retrieved from http://r4d.dfid.gov.uk/

Willingham, D. T. (2007). Critical thinking. American Educator. American Federation of Teachers.

Xu, M., David, J. M., \& Kim, S. H. (2018). The fourth industrial revolution: Opportunities and challenges. International Journal of Financial Research, 9(2), 90-95. https://doi.org/10.5430/ijfr.v9n2p90

Zohar, A., \& Dori, Y. J. (2003). Higher-Order Thinking Skills and LowAchieving Students: Are They Mutually Exclusive? Journal of the Learning Sciences, 12(2), 265-272. https://doi.org/10.1207/S15327809JLS1202 